\title{
The best salt solution parameter to describe seed/seedling responses to saline and sodic salts
}

\author{
Hongxiang Zhang • Yu Tian • Bo Guan • \\ Daowei Zhou (D) - Zewei Sun • Carol C. Baskin
}

Received: 22 January 2018 / Accepted: 6 March 2018

C) Springer International Publishing AG, part of Springer Nature 2018

\begin{abstract}
Background and aims Results of studies on plant responses to salt stress often are difficult to compare because different salt parameters were used. Our aim was to compare the effects of different combinations of sodium salts on germination/seedling growth of two forage species and determine which salt solution parameter(s) was(were) most closely related to these responses.

Methods Seeds of the legume Medicago sativa and the grass Elymus dahuricus were germinated in different
\end{abstract}

Responsible Editor: Jeffrey Walck.

Electronic supplementary material The online version of this article (https://doi.org/10.1007/s11104-018-3623-8) contains supplementary material, which is available to authorized users.

H. Zhang $\cdot$ D. Zhou $(\bowtie)$

Jilin Provincial Laboratory of Grassland Farming, Northeast Institute of Geography and Agroecology, Chinese Academy of Sciences, Changchun 130102, China

e-mail: zhoudaowei@iga.ac.cn

Y. Tian $\cdot$ Z. Sun $(\bowtie)$

Animal Science and Technology College, Jilin Agricultural University, Changchun 130118, China

e-mail: sunzewei@jlau.edu.cn

B. Guan

Key Laboratory of Coastal Environmental Processes and Ecological Remediation, Yantai Institute of Coastal Zone Research, Chinese Academy of Sciences, Yantai 264003, China

C. C. Baskin

Department of Biology, University of Kentucky, Lexington, KY 40506, USA and Department of Plant and Soil Sciences, University of Kentucky, Lexington, KY 40546, USA concentrations of saline and sodic salts. Various parameters of the salt solutions were determined, and seed germination and seedling growth metrics were measured. Results Seeds of both species were more tolerant to saline than to sodic salts, and seedlings of E. dahuricus were more salt tolerant than those of $M$. sativa. $\mathrm{Na}_{2} \mathrm{SO}_{4}$ and $\mathrm{Na}_{2} \mathrm{CO}_{3}$ were more inhibitory to germination/growth of the two study species than the same concentration of $\mathrm{NaCl}$ and $\mathrm{NaHCO}_{3}$ for saline and sodic salts, respectively. For both species, electrical conductivity, salt content (\%) and $\mathrm{Na}^{+}$concentration best correlated with germination/growth for saline salts and $\mathrm{Na}^{+}$concentration for sodic salts.

Conclusions In evaluating the effects of salt on seed germination and seedling growth, both saline and sodic salts need to be considered, and $\mathrm{Na}^{+}$concentration is the best salt solution parameter to use in comparing and communicating the results.

Keywords $\mathrm{EC} \cdot \mathrm{Na}^{+} \cdot \mathrm{pH} \cdot$ Saline salts $\cdot$ Sodic salts . Water potential
Abbreviations
EC Electrical conductivity
$\Psi_{\mathrm{p}} \quad$ Water potential
C Salt concentration
S Salt content
GP Germination percentage
GT Time to start of germination
RL Root length
SL Shoot length
Ch Chlorophyll content 


\section{Introduction}

Salinization is a serious problem that increases annually, thus affecting agricultural production and the environment (Farooq et al. 2017). Salt-affected areas cover more than $7 \%$ of the earth's land surface (Panta et al. 2014) and $20 \%$ of the global irrigated lands in at least 100 countries (Jesus et al. 2015). The global annual cost of salt-affected crop production loss in irrigated areas is estimated to be US\$27.3 billion (Qadir et al. 2014). Given that little new productive land is available, utilization of salt-affected land and productivity enhancement of crops and forages in salt-affected soils are exclusive options for feeding the expanding world population (Qudir et al. 2008). Thus a comprehensive understanding of salt effects on growth of plant species with potential to be used for agriculture production in salt-affected soils is an important issue.

Salt sensitivity of a given plant species varies with the growth stage (Hassan et al. 2017), with seed germination and early seedling growth being the most vulnerable stages (Dodd and Donovan 1999). Thus, seedling establishment is a bottleneck that must be solved, whether for crop production or phytoremediation in salt-affected soils. Therefore, germination and seedling growth responses of glycophytes (plants that are adapted to low- $\mathrm{Na}^{+}$environments, Assaha et al. 2017) (Guan et al. 2009; Nichols et al. 2009; Bina and Bostani 2017) and germination tolerance mechanisms of halophytes (plants that are adapted to saline environments, Flowers et al. 1986) to salts (Ungar 1996; Li et al. 2010a; Zhang et al. 2010; Lin et al. 2016a) have attracted much research attention.

$\mathrm{NaCl}$ is the major component in salt-affected soils (Soriano et al. 2014) and thus has been widely used to investigate the effects of salts on germination and seedling growth (Ungar 1996; Song et al. 2005; Hanif et al. 2017). However, in addition to $\mathrm{Na}^{+}$and $\mathrm{Cl}^{-}$, there are many other cations (e.g. $\mathrm{Mg}^{2+}, \mathrm{Ca}^{2+}, \mathrm{K}^{+}$) and anions (e.g. $\mathrm{SO}_{4}{ }^{2-}, \mathrm{CO}_{3}{ }^{2-}, \mathrm{HCO}_{3}{ }^{-}$) in salt-affected soils (Qadir et al. 2000). The influence of single salts, other than $\mathrm{NaCl}$, on plant growth has been investigated, and these studies include all the kinds of salts known to occur in salt-affected soils (Egan et al. 1997; Sosa et al. 2005; Zhang et al. 2015). Some studies on responses of seeds/ seedlings to increased salinity have used mixtures of two or more kinds of salts (Yang et al. 2007; Zhang and $\mathrm{Mu}$ 2009; Li et al. 2010a, b; Guo et al. 2011; Lin et al. 2014; Zhao et al. 2014). However, the differences between main single salts and between single salts and mixed salts on seed germination and plant growth remain unclear. For example, what are the differences in germination and seedling growth responses of a plant species at $100 \mathrm{mM} \mathrm{NaCl}, \mathrm{Na}_{2} \mathrm{SO}_{4}, \mathrm{NaCl}: \mathrm{Na}_{2} \mathrm{SO}_{4}$ and $\mathrm{NaCl}: \mathrm{Na}_{2} \mathrm{SO}_{4}: \mathrm{NaHCO}_{3}: \mathrm{Na}_{2} \mathrm{CO}_{3}$ ? By making these comparisons, we can better understand the influences of various salts in mixture, which will allow us to extrapolate results from laboratory studies to field conditions with increased reliability.

Salt-affected soils are divided into three categories: sodic (alkaline), saline and saline-sodic soils. Sodic soils contain excess $\mathrm{Na}^{+}$, high concentration of $\mathrm{CO}_{3}{ }^{2-}$ or $\mathrm{HCO}_{3}{ }^{-}$with high $\mathrm{pH}(>8.5)$, high sodium absorption ratio (SAR, $>13$ ) or exchangeable sodium percentage (ESP, >15) and soil structural problems (Qadir et al. 2000). Saline soils also have a preponderance of $\mathrm{Na}^{+}$ with the dominant anions being $\mathrm{Cl}^{-}$and $\mathrm{SO}_{4}{ }^{2-}$, low $\mathrm{pH}$ and high electrical conductivities $\left(>4 \mathrm{dS} \mathrm{m}^{-1}\right)$ (Flowers and Flowers 2005). The characteristics of saline-sodic soils are intermediate between the two categories. Parameters such as water potential, solution concentration, salt content, $\mathrm{pH}$ and electrical conductivity can be used to help characterize the three kinds of salt-affected soils. The effects of each parameter on plant growth have been studied, and two or three of them have been compared in some studies (Shi and Wang 2005; Wehr et al. 2016). However, we do not know which of these parameter(s) is(are) most closely related to seed germination and plant growth. Thus, information on plant responses to salt and the salt solution parameters that best correlate with them is needed to plan for effective restoration and utilization of salt-affected soils.

The Songnen grassland in northeast China is famous for its productive pastures, but salinizationalkalinization has become a serious problem (Zhang et al. 2013). Thus, restoration and utilization of salinesodic Songnen grassland is an urgent ecological and economic issue. Medicago sativa (Fabaceae) and Elymus dahuricus (Poaceae) are promising perennial forage species for use in this region. Medicago sativa has high nutritional value and moderate salt tolerance (Farissi et al. 2011), and E. dahuricus is known not only for its nutritional value but also for its high tolerance to cold, drought and salt (Zhang and Nan 2007). However, information is still lacking about how the seed germination and seedling establishment phases of these two glycophytic forage species (Zhao et al. 2002) respond to saline and sodic salts (Li et al. 2010b; Sun et al. 2016). 
Thus, the objectives of our study were to determine: 1) the effects of different sodium salts on germination and early seedling responses of Medicago sativa and Elymus dahuricus, 2) the effects of different combinations of sodium salts (single, two mixed, four mixed) on seeds/ seedlings, and 3) which parameter(s) of salts is(are) most closely related to the seed germination and seedling growth responses to increased salinities.

\section{Materials and methods}

Seed collection and storage

Seeds of Medicago sativa and Elymus dahuricus were collected from more than 50 plants in autumn from western Jilin Province $\left(44^{\circ} 33^{\prime} \mathrm{N}, 123^{\circ} 31^{\prime} \mathrm{E}\right)$ in China and stored dry in cloth bags at room temperature for 8 months to break physiological dormancy of E. dahuricus before the experiment was initiated.

\section{Salt treatments}

Seven different kinds/combinations of sodium salts were used: four single salts $\mathrm{NaCl}, \mathrm{Na}_{2} \mathrm{SO}_{4}, \mathrm{NaHCO}_{3}$ and $\mathrm{Na}_{2} \mathrm{CO}_{3}$; a 1:1 molar ratio mixture of $\mathrm{NaCl}: \mathrm{Na}_{2} \mathrm{SO}_{4}$ and of $\mathrm{NaHCO}_{3}: \mathrm{Na}_{2} \mathrm{CO}_{3}$; and a 1:1:1:1 molar ratio mixture of $\mathrm{NaCl}: \mathrm{Na}_{2} \mathrm{SO}_{4}: \mathrm{NaHCO}_{3}: \mathrm{Na}_{2} \mathrm{CO}_{3}$. Based on results of a preliminary experiment, concentrations of the saline salts $\left(\mathrm{NaCl}, \mathrm{Na}_{2} \mathrm{SO}_{4}, \mathrm{NaCl}: \mathrm{Na}_{2} \mathrm{SO}_{4}\right)$ used for $M$. sativa were $40,60,80,100,120,160,200$ and $240 \mathrm{mM}$, and concentrations of the sodic salts $\left(\mathrm{NaHCO}_{3}, \quad \mathrm{Na}_{2} \mathrm{CO}_{3}, \quad \mathrm{NaHCO}_{3}: \mathrm{Na}_{2} \mathrm{CO}_{3}\right.$, $\mathrm{NaCl}: \mathrm{Na}_{2} \mathrm{SO}_{4}: \mathrm{NaHCO}_{3}: \mathrm{Na}_{2} \mathrm{CO}_{3}$ ) used were set at 10 , 20, 40, 60 and $80 \mathrm{mM}$. For E. dahuricus, concentrations of the saline salts were set at 40, 80, 120,160, 200, 240, 320 and $400 \mathrm{mM}$ and those of the sodic salts at 20,40, $6080,100,120,160$ and $200 \mathrm{mM}$. Distilled water was used as $0 \mathrm{mM}$ salt treatments. These concentrations were chosen to achieve germination from 100 to $0 \%$. Electrical conductivity (EC) and $\mathrm{pH}$ of all salt solutions were measured by DDS-307 and PHS-3C instruments (INESAS Scientific Instrument Co., Ltd., Shanghai, China), respectively. Water potential of each salt solution was measured with a WP4-T Dewpoint Potentia Meter (USA). Salt content $(\%)$ and $\mathrm{Na}^{+}$concentration $(\mathrm{mM})$ of each solution were calculated (Table 1). The salt content in the soil of Songnen grassland was reported to be $0.7-1 \%$ ( $\mathrm{Lu}$ et al. 1998), which is equivalent to $120-171 \mathrm{mM} \mathrm{NaCl}$.

Germination experiment

The experiment was conducted in programmed incubators with a 12-h daily photoperiod (Sylvania cool white fluorescent lamps, $100 \mu \mathrm{mol} \mathrm{m} \mathrm{m}^{-2} \mathrm{~s}^{-1}$, 400-700 nm) at $25 / 15{ }^{\circ} \mathrm{C}$ day/night temperature. Seeds of both species were surface sterilised in $0.1 \% \mathrm{KMnO}_{4}$ for $10 \mathrm{~min}$ and rinsed with distilled water. They were then sown on two folds of filter paper placed in 9-cm-diameter new plastic Petri dishes with $10 \mathrm{ml}$ of the test solution. There were three replicates with 50 seeds for each species in each salt treatment and in distilled water. The Petri dishes were sealed with Parafilm to prevent evaporation of water. The salt solutions and Parafilm were replaced as necessary. Seeds were considered to have germinated upon emergence of the radicle. Germination was recorded every four hours at the beginning and then daily when the germination speed decreased. The experimental period lasted for 14 days, at which time germination had stopped. Final germination percentage and time to start germination were calculated.

Five seedlings were sampled randomly from each Petri dish after 14 days to measure radicle and shoot length. Five hundred milligrams of fresh leaves from the remaining seedlings in each Petri dish were ground and extracted with acetone-ethanol solutions for $48 \mathrm{~h}$. Absorbance (A) was measured at 663 and $645 \mathrm{~nm}$ with a spectrophotometer (UV-1800, SHIMADZU). The total chlorophyll content was calculated as chlorophyll a + chlorophyll $b=8.02 \mathrm{~A}_{663}+20.21 \mathrm{~A}_{645}$ (Bao et al. 2012).

Data analysis

Germination data were transformed (arcsine) before statistical analysis to ensure homogeneity of variance. GLM analysis was used to analyze the effects of species, salt type, salinity and their interactions on germination percentage, germination rate, radicle length, shoot length and chlorophyll content. Multiple comparison tests were used to compare differences among treatment means at the 0.05 level. Pearson correlation between early seedling metrics and salt parameters was analyzed. Statistical analyses were carried out in SPSS (version 18.0, SPSS Inc., Chicago, Illinois, USA). 
Table 1 Salt concentration $(\mathrm{C}, \mathrm{mM})$, sodium ion concentration $\left(\mathrm{Na}^{+}, \mathrm{mM}\right)$, salt content $(\mathrm{S}, \%$ or $\mathrm{g} / 100 \mathrm{~g}), \mathrm{pH}$, water potential $\left(\Psi_{\mathrm{p}}\right.$, $\mathrm{MPa})$ and electrical conductivity $(\mathrm{EC}, \mathrm{dS} / \mathrm{m})$ of different salt solutions

\begin{tabular}{|c|c|c|c|c|c|c|}
\hline Salt types & $\mathrm{C}$ & $\mathrm{Na}^{+}$ & $\mathrm{S}$ & $\mathrm{pH}$ & $\Psi_{\mathrm{p}}$ & $\mathrm{EC}$ \\
\hline Control & 0 & 0 & 0 & 6.03 & 0.00 & 0.01 \\
\hline \multirow[t]{9}{*}{$\mathrm{NaCl}$} & 40 & 40 & 0.23 & 6.28 & -0.14 & 3.36 \\
\hline & 60 & 60 & 0.35 & 6.89 & -0.38 & 4.90 \\
\hline & 80 & 80 & 0.47 & 6.00 & -0.46 & 6.46 \\
\hline & 100 & 100 & 0.59 & 6.62 & -0.53 & 7.84 \\
\hline & 120 & 120 & 0.70 & 6.15 & -0.59 & 9.25 \\
\hline & 160 & 160 & 0.94 & 6.01 & -0.70 & 12.11 \\
\hline & 200 & 200 & 1.17 & 6.13 & -0.84 & 14.65 \\
\hline & 240 & 240 & 1.40 & 6.51 & -1.12 & 17.00 \\
\hline & 320 & 320 & 1.87 & 6.43 & -1.39 & 21.90 \\
\hline \multirow[t]{9}{*}{$\mathrm{Na}_{2} \mathrm{SO}_{4}$} & 40 & 80 & 0.57 & 6.56 & -0.32 & 5.47 \\
\hline & 60 & 120 & 0.85 & 6.43 & -0.38 & 7.66 \\
\hline & 80 & 160 & 1.14 & 5.89 & -0.48 & 9.84 \\
\hline & 100 & 200 & 1.42 & 6.68 & -0.53 & 11.82 \\
\hline & 120 & 240 & 1.70 & 6.34 & -0.83 & 13.78 \\
\hline & 160 & 320 & 2.27 & 6.23 & -0.94 & 17.27 \\
\hline & 200 & 400 & 2.84 & 6.19 & -1.07 & 20.80 \\
\hline & 240 & 480 & 3.41 & 5.79 & -1.31 & 23.50 \\
\hline & 320 & 640 & 4.54 & 5.98 & -1.73 & 29.30 \\
\hline \multirow[t]{9}{*}{$\mathrm{NaCl}: \mathrm{Na}_{2} \mathrm{SO}_{4}$} & 40 & 60 & 0.40 & 6.93 & -0.27 & 4.54 \\
\hline & 60 & 90 & 0.60 & 6.64 & -0.38 & 6.40 \\
\hline & 80 & 120 & 0.80 & 6.11 & -0.44 & 8.44 \\
\hline & 100 & 150 & 1.00 & 5.91 & -0.48 & 10.02 \\
\hline & 120 & 180 & 1.20 & 6.29 & -0.63 & 11.77 \\
\hline & 160 & 240 & 1.60 & 6.00 & -0.79 & 15.20 \\
\hline & 200 & 300 & 2.01 & 5.82 & -1.02 & 18.05 \\
\hline & 240 & 360 & 2.41 & 5.81 & -1.28 & 20.50 \\
\hline & 320 & 480 & 3.21 & 6.12 & -1.66 & 26.60 \\
\hline \multirow[t]{8}{*}{$\mathrm{NaHCO}_{3}$} & 10 & 10 & 0.08 & 8.70 & -0.12 & 0.78 \\
\hline & 20 & 20 & 0.17 & 8.80 & -0.15 & 1.35 \\
\hline & 40 & 40 & 0.34 & 8.87 & -0.17 & 2.47 \\
\hline & 60 & 60 & 0.50 & 8.80 & -0.32 & 3.62 \\
\hline & 80 & 80 & 0.67 & 8.70 & -0.38 & 4.69 \\
\hline & 100 & 100 & 0.84 & 8.72 & -0.50 & 5.67 \\
\hline & 120 & 120 & 1.01 & 8.51 & -0.55 & 6.76 \\
\hline & 160 & 160 & 1.34 & 8.48 & -0.71 & 8.69 \\
\hline \multirow[t]{6}{*}{$\mathrm{Na}_{2} \mathrm{CO}_{3}$} & 10 & 20 & 0.11 & 11.01 & -0.06 & 1.62 \\
\hline & 20 & 40 & 0.21 & 11.20 & -0.14 & 2.91 \\
\hline & 40 & 80 & 0.42 & 11.21 & -0.27 & 5.32 \\
\hline & 60 & 120 & 0.64 & 11.43 & -0.37 & 7.50 \\
\hline & 80 & 160 & 0.85 & 11.42 & -0.43 & 9.44 \\
\hline & 100 & 200 & 1.06 & 11.44 & -0.53 & 11.41 \\
\hline
\end{tabular}

Table 1 (continued)

\begin{tabular}{lrrrllr}
\hline Salt types & $\mathrm{C}$ & $\mathrm{Na}^{+}$ & $\mathrm{S}$ & $\mathrm{pH}$ & \multicolumn{1}{l}{$\Psi_{\mathrm{p}}$} & \multicolumn{1}{l}{$\mathrm{EC}$} \\
\hline & 120 & 240 & 1.27 & 11.36 & -0.70 & 13.28 \\
& 160 & 320 & 1.70 & 11.30 & -0.96 & 16.66 \\
$\mathrm{NaHCO}_{3}: \mathrm{Na}_{2} \mathrm{CO}_{3}$ & 10 & 15 & 0.10 & 10.25 & -0.10 & 1.12 \\
& 20 & 30 & 0.19 & 10.23 & -0.18 & 2.08 \\
& 40 & 60 & 0.38 & 10.17 & -0.27 & 3.88 \\
& 60 & 90 & 0.57 & 10.15 & -0.38 & 5.54 \\
& 80 & 120 & 0.76 & 10.12 & -0.42 & 7.08 \\
& 100 & 150 & 0.95 & 10.11 & -0.58 & 8.47 \\
$\mathrm{NaCl} \mathrm{Na}_{2} \mathrm{SO}_{4}:$ & 120 & 180 & 1.14 & 10.03 & -0.66 & 9.93 \\
$\mathrm{NaHCO}_{3}: \mathrm{Na}_{2} \mathrm{CO}_{3}$ & 160 & 240 & 1.52 & 9.99 & -0.85 & 12.68 \\
& 10 & 15 & 0.10 & 10.54 & -0.16 & 1.26 \\
& 30 & 0.20 & 10.58 & -0.19 & 2.26 \\
& 40 & 60 & 0.39 & 10.06 & -0.26 & 4.25 \\
& 60 & 90 & 0.59 & 10.14 & -0.34 & 6.06 \\
& 80 & 120 & 0.78 & 10.08 & -0.45 & 7.68 \\
& 100 & 150 & 0.98 & 10.09 & -0.62 & 9.34 \\
& 120 & 180 & 1.17 & 9.99 & -0.69 & 10.96 \\
& 160 & 240 & 1.56 & 9.95 & -0.89 & 13.98 \\
\hline & & & & & &
\end{tabular}

\section{Results}

Salt type, salinity, species and their interactions had significant effects on seed germination and seedling growth whether the data for saline salts and sodic salts were analyzed together or separately $(P<0.05)$, except species $\times$ salt type effect on germination rate for sodic salts $(P=0.189)$.

As salinity increased, germination percentages of the two species decreased (Fig. 1). Seeds of the two species germinated in higher concentrations of saline than in sodic salts. Germination percentages for both species were highest in $\mathrm{NaCl}$ or $\mathrm{NaHCO}_{3}$ and lowest in $\mathrm{Na}_{2} \mathrm{SO}_{4}$ or $\mathrm{Na}_{2} \mathrm{CO}_{3}$ solutions at the same concentration among the three saline salts and four sodic salts, respectively, with those of seeds in the mixed solutions being intermediate. Seeds of E. dahuricus germinated at higher salinities than those of $M$. sativa in the same salt concentration.

The time lag to start of germination increased with salinity, from $1 \mathrm{~d}$ in distilled water to around $4 \mathrm{~d}$ in $240 \mathrm{mM} \mathrm{NaCl}$ for $M$. sativa and from around $2 \mathrm{~d}$ in distilled water to $12 \mathrm{~d}$ in $100 \mathrm{mM} \mathrm{Na}_{2} \mathrm{CO}_{3}$ solution for E. dahuricus (Fig. 2). However, the time to start of germination decreased significantly at 


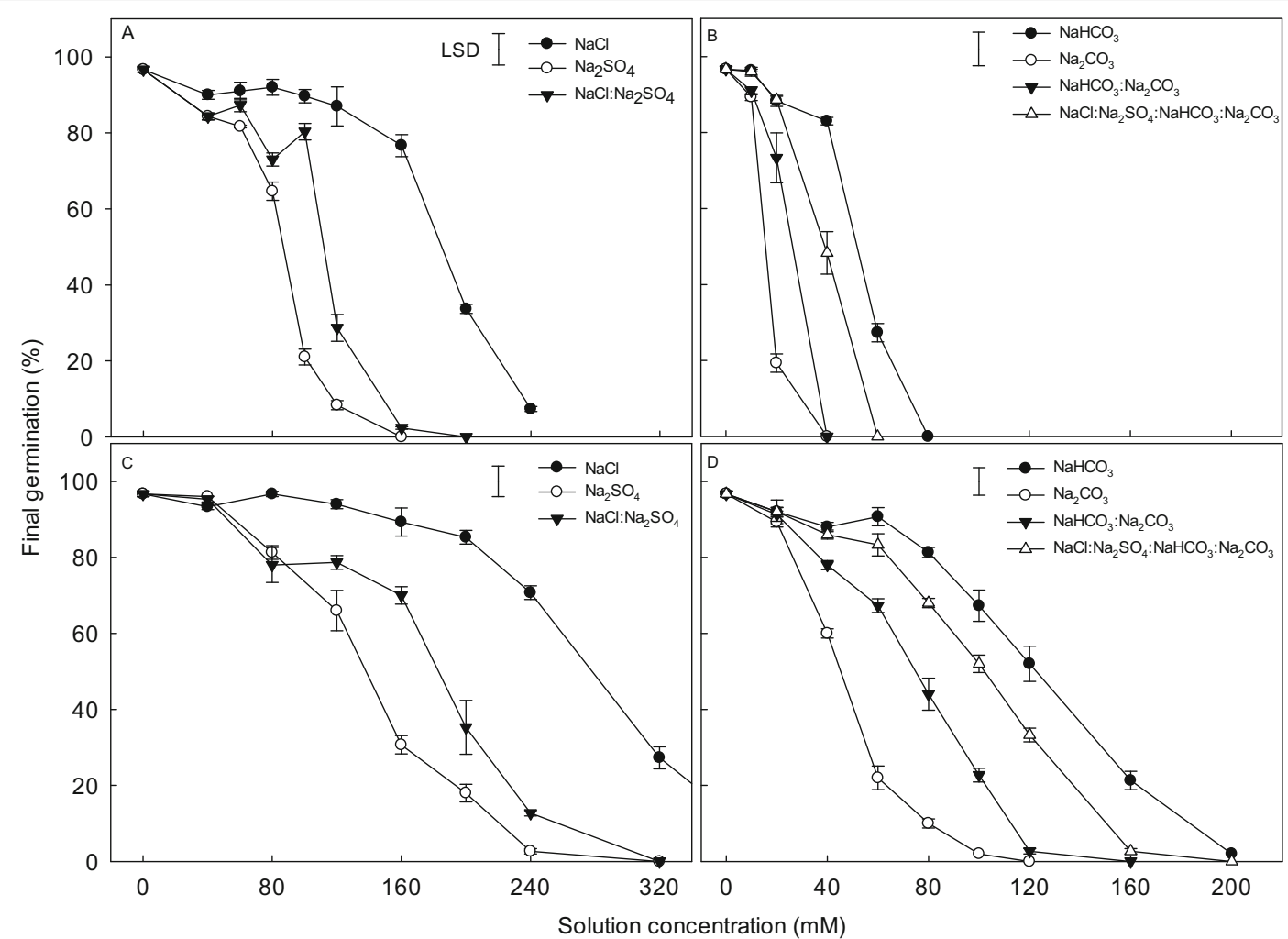

Fig. 1 Final germination percentage of $M$. sativa $(\mathbf{a}, \mathbf{b})$ and $E$. dahuricus $(\mathbf{c}, \mathbf{d})$ at different concentrations of saline (a, c) and sodic $(\mathbf{b}, \mathbf{d})$ salts

lower salinities compared with that in distilled water for $M$. sativa $(P<0.05) . \mathrm{Na}_{2} \mathrm{SO}_{4}$ and $\mathrm{Na}_{2} \mathrm{CO}_{3}$ had the greatest negative effects on germination time (largest increase in time to start of germination) among saline and sodic salts, respectively.

All single and combinations of salts tested greatly influenced radicle length of both species (Fig. 3). Among the saline salts, $\mathrm{Na}_{2} \mathrm{SO}_{4}$ had more inhibitory effects on radicle length than $\mathrm{NaCl}$. Even $40 \mathrm{mM}$ $\mathrm{Na}_{2} \mathrm{SO}_{4}$ decreased radicle length of $M$. sativa and E. dahuricus $70.3 \%$ and $58.6 \%$, respectively, compared with that in distilled water. Radicle length of the two species was comparable in distilled water, but that of E. dahuricus was less affected by saline solutions than M. sativa. Among the sodic solutions, for both species, $\mathrm{NaHCO}_{3}$ had less effect on radicle length than $\mathrm{Na}_{2} \mathrm{CO}_{3}$. Radicle length in mixed solutions of the four salts was longer than that in $\mathrm{NaHCO}_{3}$ solution at low salinity, e.g. $10 \mathrm{mM}$ for M. sativa and $40 \mathrm{mM}$ for E. dahuricus. At lower salinities, $\mathrm{NaHCO}_{3}$ had less or a similar effect on radicle length of $M$. sativa than on that of E. dahuricus. For example, 20 and $40 \mathrm{mM} \mathrm{NaHCO}{ }_{3}$ decreased radicle length $1.3 \%$ and $77.0 \%$, respectively, for $M$. sativa and
$51.2 \%$ and $69.3 \%$, respectively, for E. dahuricus compared with distilled water. However, radicle length of E. dahuricus was less affected than that of $M$. sativa by sodic salts at $\geq 40 \mathrm{mM}$ salinities.

Shoot length of E. dahuricus was nearly 10 times that of M. sativa in distilled water (Fig. 4), and for both species it was much less affected by salts than radicle length. For example, a $50 \%$ decrease in shoot length occurred at $120-160 \mathrm{mM} \mathrm{NaCl}, 40-60 \mathrm{mM} \mathrm{Na}_{2} \mathrm{SO}_{4}$, 20-40 mM NaHCO 3 and $10-20 \mathrm{mM} \mathrm{Na}_{2} \mathrm{CO}_{3}$ for M. sativa and at $160-200 \mathrm{mM} \mathrm{NaCl}, 80-120 \mathrm{mM}$ $\mathrm{Na}_{2} \mathrm{SO}_{4}, 80-100 \mathrm{mM} \mathrm{NaHCO}_{3}$ and $20-40 \mathrm{mM} \mathrm{Na}_{2} \mathrm{CO}_{3}$ solutions for E. dahuricus. Shoot length of E. dahuricus was less affected than that of $M$. sativa, but low salinities of $\mathrm{NaCl}(\leq 100 \mathrm{mM})$ increased shoot growth compared with distilled water for $M$. sativa. The effects of salts on chlorophyll content were similar to those on shoot length (Fig. 5). Notably, salts had less influence on chlorophyll content of $E$. dahuricus than they did on M. sativa, especially $\mathrm{Na}_{2} \mathrm{SO}_{4}$ and $\mathrm{Na}_{2} \mathrm{CO}_{3}$.

Germination percentages, germination rates and radicle length were most strongly correlated with $\mathrm{Na}^{+}$concentration, EC and salt content (\%) in saline salts for 


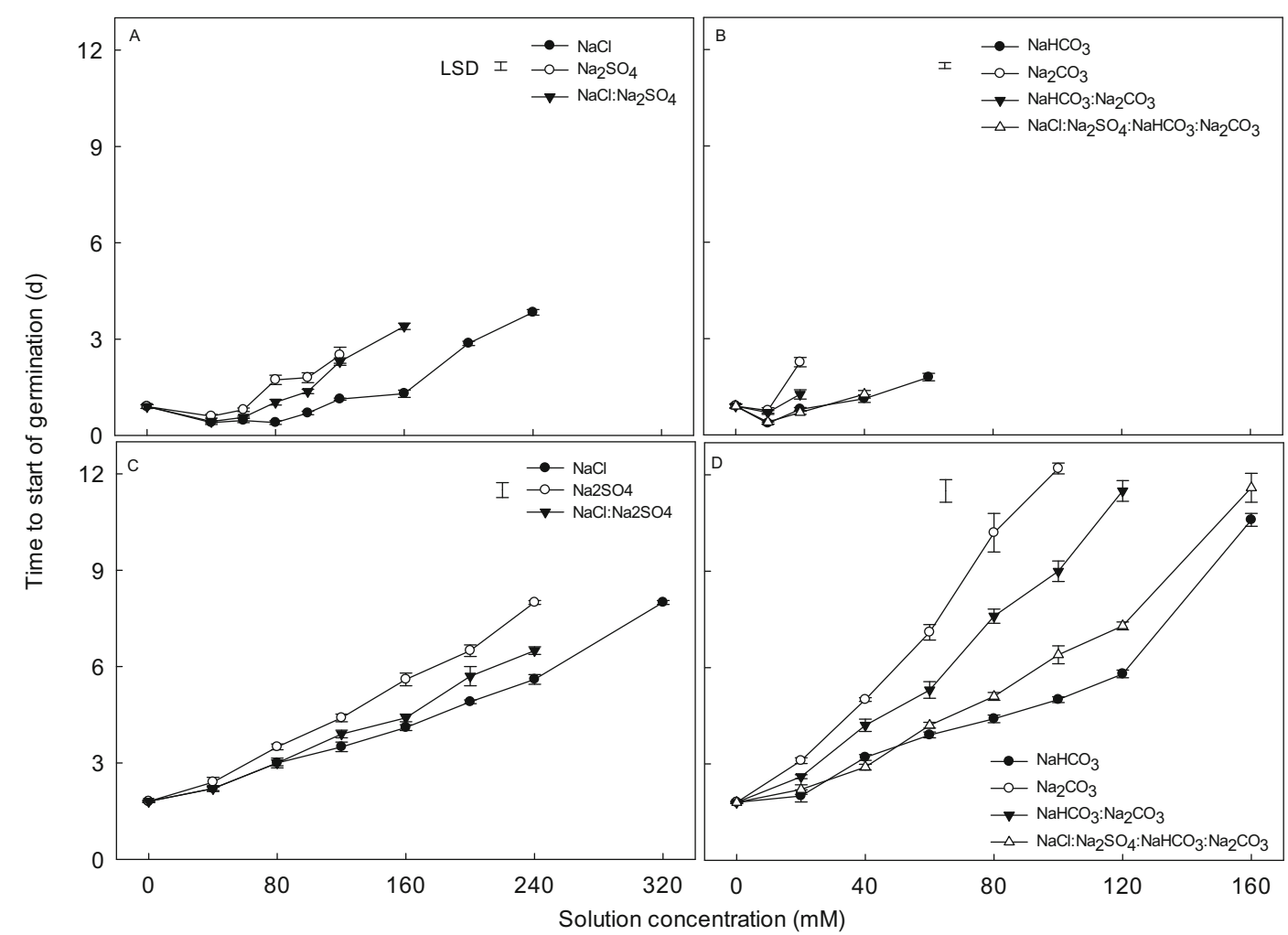

Fig. 2 Time to start of germination for M. sativa $(\mathbf{a}, \mathbf{b})$ and E. dahuricus $(\mathbf{c}, \mathbf{d})$ at different concentrations of saline $(\mathbf{a}, \mathbf{c})$ and sodic $(\mathbf{b}, \mathbf{d})$ salts

both species (Table 2). Shoot length and chlorophyll content of E. dahuricus were best correlated with EC, while for $M$. sativa they were best correlated with salt content $(\%)$ and $\mathrm{Na}^{+}$concentration. However, all germination and seedling metrics were best correlated with $\mathrm{Na}^{+}$concentration in sodic salts. When saline and sodic salts were analyzed together, germination and seedling metrics were best correlated with salt content $(\%)$ or $\mathrm{Na}^{+}$ concentration for both species. Water potential and salt concentrations were significantly correlated with germination and seedling metrics $(P<0.05)$, however, $\mathrm{pH}$ was not significantly correlated with these growth metrics for either species in most circumstances $(P>0.05)$.

\section{Discussion}

Elymus dahuricus and M. sativa are excellent candidate forage species to grow in the saline-sodic Songnen grassland region of northeast China. $M$. sativa can germinate at $>240 \mathrm{mM} \mathrm{NaCl}$ and $60 \mathrm{mM} \mathrm{NaHCO}_{3}$. The salt tolerance of $M$. sativa is comparable to that of other legume species such as Trifolium tomentosum (Nichols et al. 2009) and Acacia schaffneri (Everitt 1983). Further, seeds of E. dahuricus germinated to $21.3 \%$ and $2.0 \%$ in $320 \mathrm{mM} \mathrm{NaCl}$ and $200 \mathrm{mM} \mathrm{NaHCO}_{3}$, respectively, which indicates that it is more tolerant to saline and sodic salts than the dominant grass species Leymus chinensis (Ma et al. 2015) and the common halophytic grass species Chloris virgata (Lin et al. 2016a) in the Songnen grasslands.

\section{Effect of different kinds of salts}

Among the single salts, the effects of sodic salts $\left(\mathrm{NaHCO}_{3}\right.$ and $\left.\mathrm{Na}_{2} \mathrm{CO}_{3}\right)$ were more inhibitory than those of the saline salts $\left(\mathrm{NaCl}\right.$ and $\left.\mathrm{Na}_{2} \mathrm{SO}_{4}\right)$ on germination and seedling growth, as well as on chlorophyll content of the two species, which is consistent with results from studies on the glycophytes Medicago ruthenica (Guan et al. 2009), C. virgata (treated as halophyte in Lin et al. 2016a, but not in Zhao et al. 2002) and L. chinensis (Lin et al. 2016b). However, some halophytic species such as Atriplex undulata (Piovan et al. 2014) and Borszczowia(Suaeda) aralocaspica (Zhang et al. 2015) are more tolerant or equally tolerant to sodic than saline 


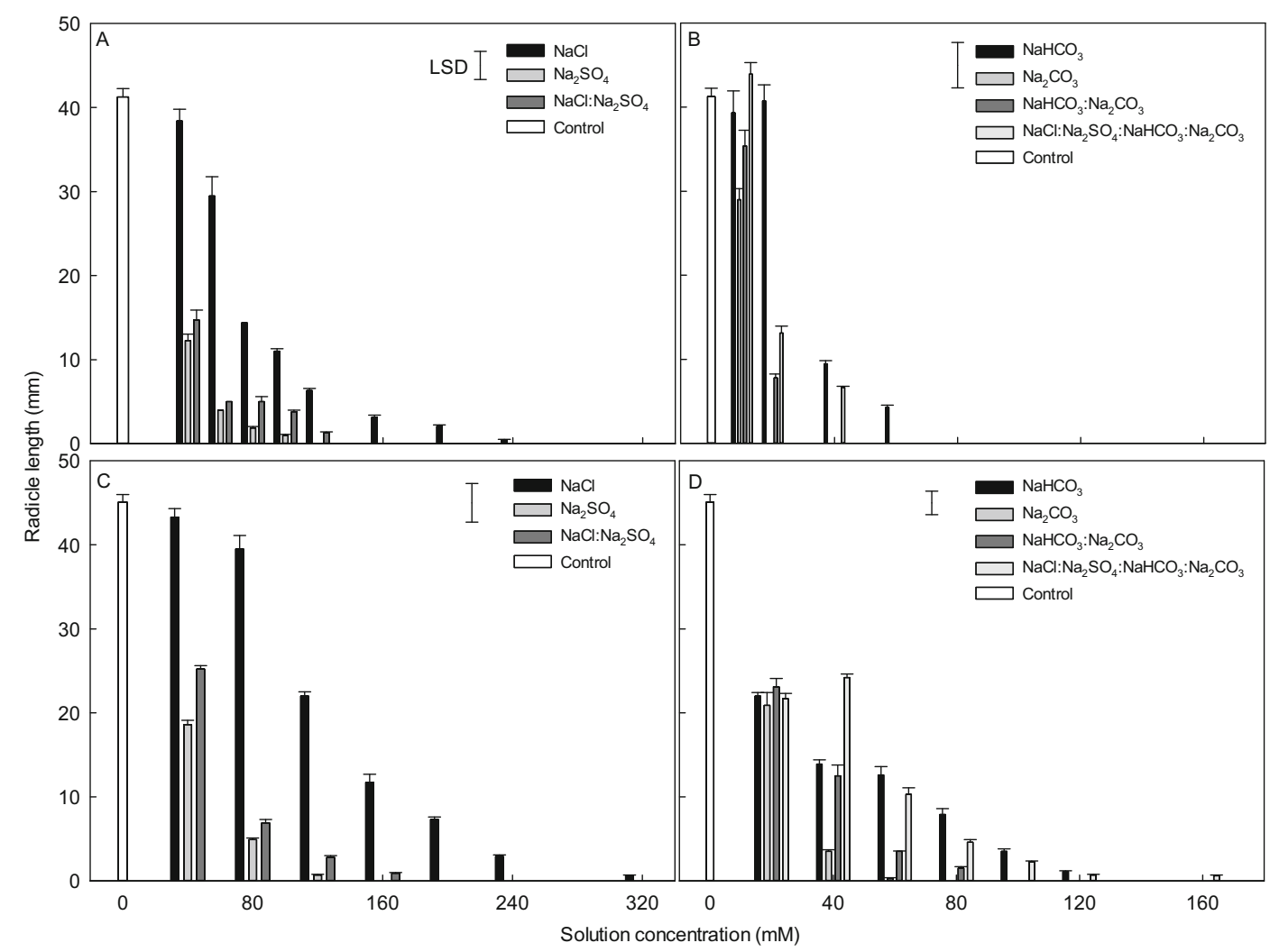

Fig. 3 Radicle length of $M$. sativa $(\mathbf{a}, \mathbf{b})$ and E. dahuricus $(\mathbf{c}, \mathbf{d})$ at different concentrations of saline (a, c) and sodic (b, d) salts

salts. In our study, $\mathrm{Na}_{2} \mathrm{SO}_{4}$ was more inhibitory than $\mathrm{NaCl}$ among saline salts and $\mathrm{Na}_{2} \mathrm{CO}_{3}$ was more inhibitory than $\mathrm{NaHCO}_{3}$ among sodic salts on germination and seedling growth of both species at the same concentrations. The results from previous studies on effects of saline/sodic salts on germination are contradictory and species dependent. For example, $\mathrm{NaCl}$ was more inhibitory than $\mathrm{Na}_{2} \mathrm{SO}_{4}$ on germination of the halophytes Arthrocnemum macrostachyum, Juncus acutus (Vicente et al. 2009) and the glycophyte Pinus halepensis (Nedjimi 2017), but $\mathrm{Na}_{2} \mathrm{SO}_{4}$ was more inhibitory than $\mathrm{NaCl}$ on germination of the halophytes Prosopis strombulifera (Sosa et al. 2005) and Ceratoides latens (Zhang et al. 2015). $\mathrm{Na}_{2} \mathrm{CO}_{3}$ was more inhibitory than $\mathrm{NaHCO}_{3}$ for germination of the glycophyte L. chinensis (Ma et al. 2015). However, germination percentages were comparable at the same concentrations of $\mathrm{NaHCO}_{3}$ and $\mathrm{Na}_{2} \mathrm{CO}_{3}$ solutions for the glycophyte Zea mays (Zhang and Zhao 2011). Halophytes are usually more tolerant to salinity than glycophytes and halophytes and glycophytes use different mechanisms to cope with salt ions (Qudir et al. 2008). However, the contradictory responses to a salt are not necessarily related to whether the species is a halophyte or glycophyte.

In our study, we also included a 1:1 molar ratio mixture of $\mathrm{NaCl}: \mathrm{Na}_{2} \mathrm{SO}_{4}$ and of $\mathrm{NaHCO}_{3}: \mathrm{Na}_{2} \mathrm{CO}_{3}$ and a 1:1:1:1 molar ratio of the four mixed salts. Compared with the results for single salts, germination and seedling growth metrics of the two mixed saline and sodic salts approached those of seeds/seedlings in $\mathrm{Na}_{2} \mathrm{SO}_{4}$ and $\mathrm{Na}_{2} \mathrm{CO}_{3}$ for both species, respectively. This means the single salt with strong effect $\left(\mathrm{Na}_{2} \mathrm{SO}_{4}\right.$ and $\left.\mathrm{Na}_{2} \mathrm{CO}_{3}\right)$ played a more important role in the two-salt mixture than the one with weak effect, regardless of saline or sodic salts. However, radicle length, shoot length and chlorophyll content of both study species in mixed salts were intermediate between those of the two single salts or approached values of $\mathrm{NaCl}$ or $\mathrm{NaHCO}_{3}$ in some low concentration treatments (Figs. 3, $4,5)$. The effect on germination traits of the four-salt mixture was intermediate between that of the $\mathrm{NaHCO}_{3}: \mathrm{Na}_{2} \mathrm{CO}_{3}$ mixture and the $\mathrm{NaHCO}_{3}$ single salt, but seedling metrics of the four-salt mixture treatment sometimes were larger than those of $\mathrm{NaHCO}_{3}$. Therefore, sodic salts predominate in the four-salt mixture, with addition of saline salts mitigating the effect of the strong 


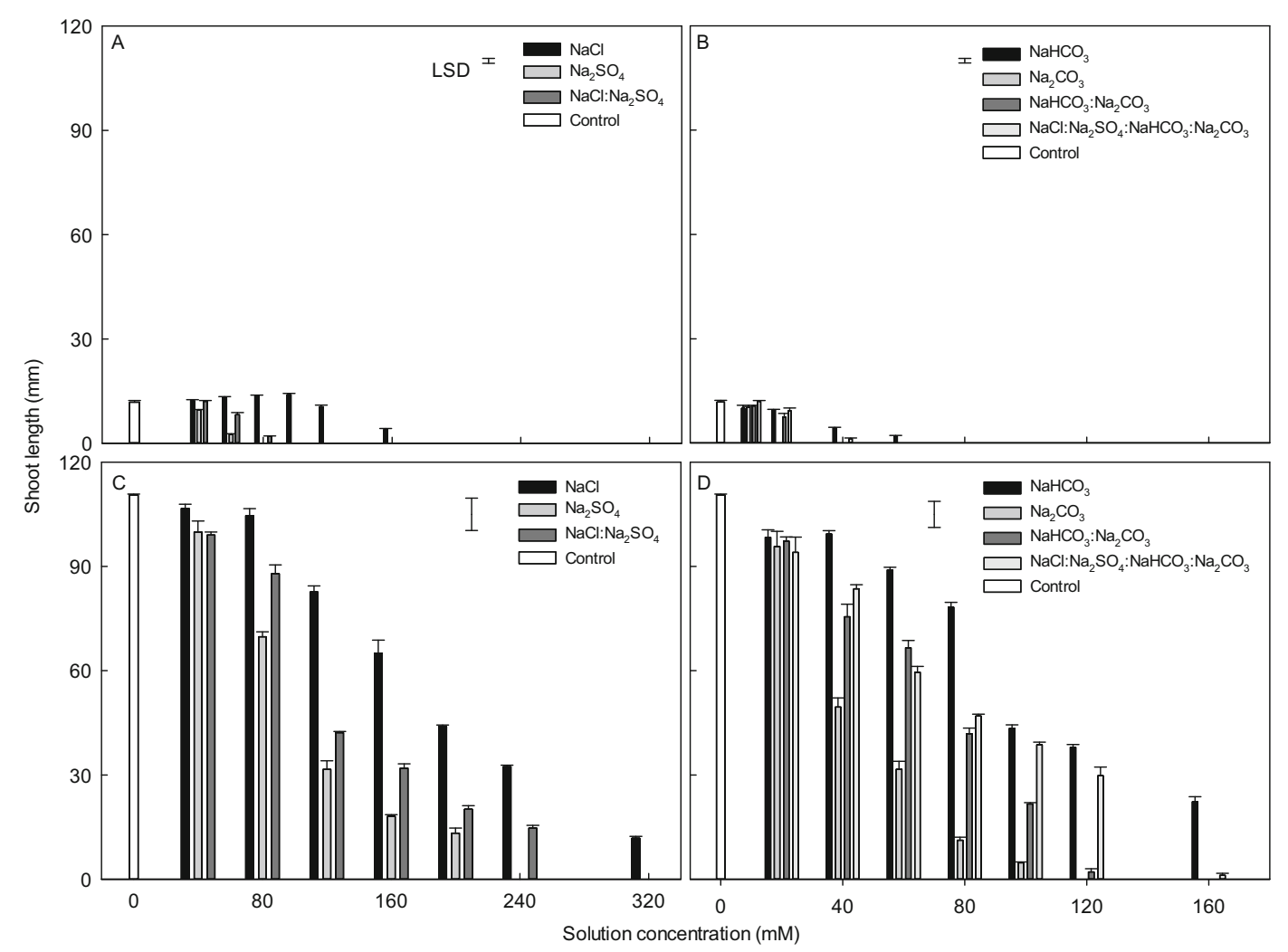

Fig. 4 Shoot length of M. sativa (a, b) and E. dahuricus $(\mathbf{c}, \mathbf{d})$ at different concentrations of saline (a, c) and sodic (b, d) salts

sodic salt $\left(\mathrm{Na}_{2} \mathrm{CO}_{3}\right)$ and enhancing the effect of the weak sodic salt $\left(\mathrm{NaHCO}_{3}\right)$. Our results agree with those of Ryan et al. (1975) that germination is affected by both the total concentration and the type of salts involved and that extrapolation of results from monosaline solutions in the laboratory to field conditions may be at best speculative (Sosa et al. 2005). Additionally, temperature can influence germination and seedling growth responses to salinity (Zhang et al. 2013). Our study investigated germination/ seedling responses to different salts under optimal temperature $\left(25 / 15^{\circ} \mathrm{C}\right)$ of the two species.

Different parameters of salt such as concentration $(\mathrm{mM})$, water potential and electrical conductivity (EC) have been used in various studies on the effects of salts on germination and seedling growth according to different experimental aims (Table S1). However, lack of consistency in use of salt solution parameters often makes it difficult to compare results from different studies.

Salt concentration $(\mathrm{mM})$

Many simulation experiments have used salt concentration levels $(\mathrm{mM})$ of either $\mathrm{NaCl}$, other single salts or mixed salts to test the effects of salt on germination and plant growth (Gul and Weber 1999; Sosa et al. 2005; Lin et al. 2014). This approach may be used because halophytes are defined as species with the ability to complete their life cycle under salinity levels of $\geq 200 \mathrm{mM} \mathrm{NaCl}$ (Flowers et al. 1986; Flowers and Colmer 2008). With this salinity level in mind, a lot of work has been done to determine the range of salt tolerance for halophytes ( $\mathrm{Li}$ et al. 2010a) as well as for glycophytes (Zhang et al. 2013). However, we found that salt concentration was not the salt parameter most closely correlated with germination and seedling growth of either study glycophytic species.

Water potential (MPa)

Saline stress usually involves osmotic effect and/or ion injury (Dodd and Donovan 1999). To distinguish the two effects, the influences of $\mathrm{NaCl}$ were compared with those of iso-osmotic PEG (Song et al. 2005; Zhang et al. 2010) or other salts (Egan et al. 1997; Sosa et al. 2005). The inhibitory effect of salts can be mainly an osmotic effect (Egan et al. 1997), ion toxicity (Shaygan et al. 


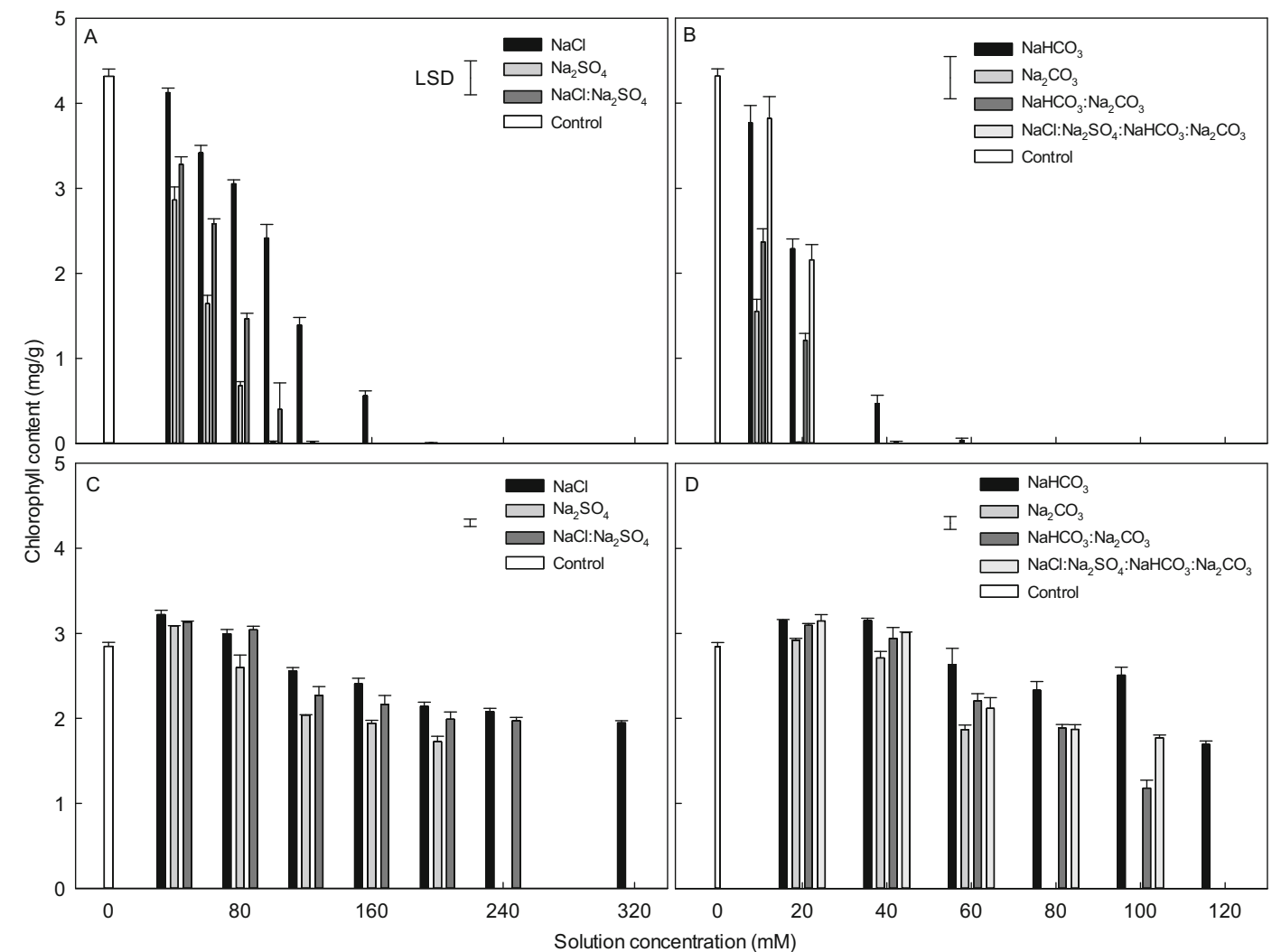

Fig. 5 Chlorophyll content of M. sativa $(\mathbf{a}, \mathbf{b})$ and E. dahuricus $(\mathbf{c}, \mathbf{d})$ at different concentrations of saline $(\mathbf{a}, \mathbf{c})$ and sodic $(\mathbf{b}, \mathbf{d})$ salts

2017) or both (Song et al. 2005), which suggests that the effect is species dependent (Dodd and Donovan 1999). Our study showed that water potential was not the salt parameter best correlated with germination and seedling growth for M. sativa or E. dahuricus in either saline or sodic conditions. However, water potential was still important, because it was significantly correlated with germination and seedling metrics in most circumstances, and the correlation coefficient was comparative to that of $\mathrm{Na}^{+}$concentration in certain cases, e.g. -0.976 for water potential and 0.944 for $\mathrm{Na}^{+}$concentration for germination rate in saline salts for E. dahuricus.

$\mathrm{pH}$

In addition to osmotic and ion stress, sodic salts induce $\mathrm{pH}$ stress (Ma et al. 2015), and many researchers have emphasized the effect of $\mathrm{pH}$ on growth of plants exposed to sodic salts (Shi and Wang 2005; Li et al. 2010a; Basto et al. 2013; Huang et al. 2017). However, pH was not correlated to germination or seedling growth in saline and sodic conditions for either species in our study. Only root length of $M$. sativa and time to start germination of E. dahuricus weakly significantly correlated to $\mathrm{pH}$, when analyzing with all salts (Table 2). Similarly, using mixtures of various proportions of $\mathrm{NaCl}, \mathrm{Na}_{2} \mathrm{SO}_{4}, \mathrm{NaHCO}_{3}$ and $\mathrm{Na}_{2} \mathrm{CO}_{3}$ to obtain different levels of salinity (25 and $50 \mathrm{mM}$ ) and $\mathrm{pH}$ (7.2-10.8), Zhang and Rue (2014) found insignificant effects of $\mathrm{pH}$ on germination of seven turfgrasses. Germination of Sorghum bicolor also was not sensitive to $\mathrm{pH}$ level (7.08-9.29) produced by mixtures of $\mathrm{NaCl}, \mathrm{Na}_{2} \mathrm{SO}_{4}$ and $\mathrm{NaHCO}_{3}$ at $\leq 200 \mathrm{mM} \mathrm{Na}^{+}$concentrations (Zhao et al. 2014). In addition, $\mathrm{pH}$ was not a limiting factor for germination of Parkinsonia aculeata, Acacia schaffneri ( $\mathrm{pH}$ 2-12, Everitt 1983), Leymus chinensis (pH 7.0-12.01, Ma et al. 2015) and Salsola foetida (pH 5-10, Hanif et al. 2017) seeds tested using buffer solutions. Therefore, $\mathrm{pH}$ may be not a good indicator of the negative effects of the salt-affected soils on the early stages of plant establishment, even in sodic conditions. 
Table 2 Pearson correlation coefficients between early seed/seedling metrics and salt parameters

\begin{tabular}{|c|c|c|c|c|c|c|c|}
\hline & & $\mathrm{pH}$ & $\mathrm{EC}$ & $\Psi_{\mathrm{p}}$ & $\mathrm{C}$ & $\mathrm{S}$ & $\mathrm{Na}^{+}$ \\
\hline & GP & 0.118 & $-0.867^{* *}$ & $0.779^{* *}$ & $-0.691^{* *}$ & $-0.917^{* *}$ & $-0.920^{* * *}$ \\
\hline Saline salts (3) & GT & -0.290 & $0.948^{\text {*** }}$ & $-0.895^{* *}$ & $0.864^{* * *}$ & $0.884^{* *}$ & $0.936^{* * *}$ \\
\hline M. sativa & RL & 0.305 & $-0.742^{* * *}$ & $0.621^{* *}$ & $-0.536^{*}$ & $-0.812^{* * *}$ & $-0.784^{* * *}$ \\
\hline \multirow[t]{3}{*}{$N=19$} & SL & 0.389 & -0.578 & 0.276 & -0.272 & $-0.825^{* *}$ & $-0.713^{*}$ \\
\hline & $\mathrm{Ch}$ & 0.477 & $-0.954^{* * *}$ & $0.798^{* *}$ & $-0.745^{* * *}$ & $-0.964^{* *}$ & $-0.982^{* * *}$ \\
\hline & GP & 0.388 & $-0.900^{* *}$ & $0.856^{* *}$ & $-0.749^{* *}$ & $-0.950^{* *}$ & $-0.952^{* * *}$ \\
\hline Saline salts (3) & GT & -0.349 & $0.979^{* * *}$ & $-0.976^{* *}$ & $0.945^{* *}$ & $0.896^{* *}$ & $0.944^{* * *}$ \\
\hline E. dahuricus & RL & 0.091 & $-0.780^{* * *}$ & $0.692^{* *}$ & $-0.595^{*}$ & $-0.874^{* * *}$ & $-0.833^{\text {** }}$ \\
\hline \multirow[t]{3}{*}{$\mathrm{N}=19$} & SL & 0.260 & $-0.967^{* * *}$ & $0.922^{* *}$ & $-0.849^{* *}$ & $-0.932^{* *}$ & $-0.959^{* *}$ \\
\hline & $\mathrm{Ch}$ & 0.302 & $-0.951^{* * *}$ & $0.909^{* *}$ & $-0.841^{* * *}$ & $-0.907^{* *}$ & $-0.936^{* *}$ \\
\hline & GP & -0.108 & $-0.808^{* *}$ & 0.591 & $-0.641^{*}$ & $-0.690^{*}$ & $-0.809^{* * *}$ \\
\hline Sodic salts (4) & GT & 0.143 & $0.733^{*}$ & -0.454 & 0.586 & $0.631^{*}$ & $0.745^{* * *}$ \\
\hline M. sativa & RL & 0.042 & $-0.845^{* *}$ & $0.690^{*}$ & $-0.766^{* *}$ & $-0.807^{* *}$ & $-0.857^{* * *}$ \\
\hline \multirow[t]{3}{*}{$N=11$} & SL & 0.379 & $-0.929^{* *}$ & $0.813^{* *}$ & $-0.930^{* * *}$ & $-0.953^{* *}$ & $-0.963^{* *}$ \\
\hline & $\mathrm{Ch}$ & -0.068 & $-0.868^{* *}$ & 0.506 & $-0.732^{*}$ & $-0.789^{* *}$ & $-0.879^{* * *}$ \\
\hline & GP & -0.298 & $-0.904^{* * *}$ & $0.797^{* *}$ & $-0.764^{* *}$ & $-0.835^{* *}$ & $-0.925^{* *}$ \\
\hline Sodic salts (4) & GT & 0.217 & $0.905^{* *}$ & $-0.822^{* *}$ & $0.809^{* * *}$ & $0.868^{* *}$ & $0.935^{* * *}$ \\
\hline E. dahuricus & RL & 0.008 & $-0.782^{* * *}$ & $0.766^{* *}$ & $-0.784^{* *}$ & $-0.795^{* *}$ & $-0.800^{* * *}$ \\
\hline \multirow[t]{3}{*}{$N=25$} & SL & -0.235 & $-0.942^{* * *}$ & $0.862^{* *}$ & $-0.829^{* * *}$ & $-0.891^{* *}$ & $-0.954^{* * *}$ \\
\hline & $\mathrm{Ch}$ & -0.035 & $-0.927^{* *}$ & $0.890^{* *}$ & $-0.844^{* * *}$ & $-0.903^{* *}$ & $-0.950^{* * *}$ \\
\hline & GP & 0.153 & $-0.648^{* * *}$ & $0.621^{* *}$ & $-0.587^{* *}$ & $-0.715^{* *}$ & $-0.703^{* * *}$ \\
\hline All salts (7) & GT & -0.225 & $0.753^{* *}$ & $-0.745^{* *}$ & $0.751^{* * *}$ & $0.752^{* *}$ & $0.773^{* * *}$ \\
\hline M. sativa & RL & $0.485^{*}$ & $-0.717^{* * *}$ & $0.660^{* *}$ & $-0.623^{* * *}$ & $-0.763^{* * *}$ & $-0.741^{* * *}$ \\
\hline \multirow[t]{3}{*}{$N=30$} & SL & -0.067 & -0.229 & 0.137 & -0.175 & $-0.445^{*}$ & -0.335 \\
\hline & $\mathrm{Ch}$ & -0.010 & $-0.495^{* *}$ & $0.420^{*}$ & $-0.461^{*}$ & $-0.566^{* *}$ & $-0.548^{* * *}$ \\
\hline & GP & -0.176 & $-0.608^{* * *}$ & $0.598^{* *}$ & $-0.536^{* *}$ & $-0.657^{* *}$ & $-0.685^{* * *}$ \\
\hline All salts (7) & GT & $0.307^{*}$ & $0.452^{* *}$ & $-0.472^{* *}$ & $0.454^{* *}$ & $0.453^{* *}$ & $0.497^{* * *}$ \\
\hline E. dahuricus & $\mathrm{RL}$ & -0.150 & $-0.553^{* *}$ & $0.552^{* *}$ & $-0.485^{* *}$ & $-0.679^{* *}$ & $-0.640^{* * *}$ \\
\hline \multirow[t]{2}{*}{$N=44$} & SL & -0.066 & $-0.743^{* *}$ & $0.737^{* *}$ & $-0.686^{* * *}$ & $-0.758^{* *}$ & $-0.792^{* * *}$ \\
\hline & $\mathrm{Ch}$ & 0.032 & $-0.626^{* *}$ & $0.648^{* *}$ & $-0.606^{* *}$ & $-0.651^{* *}$ & $-0.661^{* *}$ \\
\hline
\end{tabular}

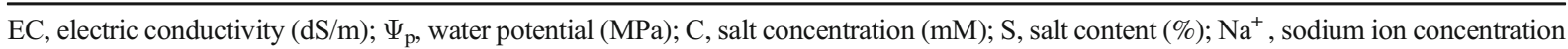
(mM); GP, germination percentage; GT, time to start of germination; RL, radicle length; SL, shoot length; Ch, chlorophyll content. Correlation coefficients in bold are the highest values for each seed/seedling metric, which means the best correlated parameter for the growth metric

* Correlation is significant at the 0.05 level

** Correlation is significant at the 0.01 level

EC $(\mathrm{dS} / \mathrm{m})$ and salt content $(\%)$

EC and salt content (\%) have been relatively less frequently used than salt concentration $(\mathrm{mM})$ and water potential to simulate salt effects on germination and seedling growth (Ungar 1996; Bina and Bostani 2017). However, these two salt parameters were preferred by some researchers for use in crop production and field studies in salt-affected soils (Qudir et al. 2008; Kanawapee et al. 2012; Glenn et al. 2013). The "bent stick" plant growth curve to salinity was based on EC of saline soils (Maas and Hoffman 1977; Barrett-Lennard 2002). In our study, EC was the most highly correlated salt parameter for time to start of germination for both study species and for shoot length and chlorophyll content for E. dahuricus in saline salts. Salt content (\%) was the most highly correlated salt parameter to predict root length response for both species and to predict shoot length for M. sativa in saline salts. Salt 
content was most highly correlated with germination percentage and seedling parameters for $M$. sativa and root length for E. dahuricus, when all saline and sodic salts were analyzed.

$\mathrm{Na}^{+}$concentration

Sodium absorption ratio (SAR) or exchangeable sodium percentage (ESP) is a very important parameter to measure in salt-affected soils, especially in sodic soils (Qadir et al. 2000; Wehr et al. 2016). However, $\mathrm{Na}^{+}$concentration has not been emphasized enough in previous laboratory studies on salt effects. We found that $\mathrm{Na}^{+}$concentration was the most strongly correlated salt solution parameter in sodic salts for germination and seedling growth of both study species. In saline salts, $\mathrm{Na}^{+}$concentration was the most closely correlated salt solution parameter for germination percentage of both species and for chlorophyll content of $M$. sativa. Therefore, $\mathrm{Na}^{+}$ concentration was the best indicator of seed/seedling response in all saline and sodic salts. Zhao et al. (2014) also stated that $\mathrm{Na}^{+}$concentration significantly influenced seed germination and seedling growth of Sorghum bicolor using different proportions of saline and sodic salts in mixture. Ryan et al. (1975) compared the effects of various salt types based on milliequivalents per liter (meq/l). Since $\mathrm{Na}^{+}$concentration was the most important salt parameter, meq $/ 1$ of $\mathrm{Na}^{+}$ may be a good unit to use in salt-effect studies with different types of salts, including monosaline and divalent salts. For example, $100 \mathrm{meq} / \mathrm{l} \mathrm{NaCl}$ equals $100 \mathrm{mM}$ $\mathrm{NaCl}$, while 100 meq/1 $\mathrm{Na}_{2} \mathrm{SO}_{4}$ equals $50 \mathrm{mM} \mathrm{Na}_{2} \mathrm{SO}_{4}$ and $100 \mathrm{mM}$ of $\mathrm{Na}^{+}$.

\section{Conclusions}

Elymus dahuricus is more salt tolerant than $M$. sativa at the seedling establishment stage, and for both species sodic salts were more inhibitory than saline salts. $\mathrm{NaCl}$ and $\mathrm{NaHCO}_{3}$ affected germination and seedling growth less negatively than $\mathrm{Na}_{2} \mathrm{SO}_{4}$ and $\mathrm{Na}_{2} \mathrm{CO}_{3}$ at the same concentrations for saline and sodic salts, respectively, with two-salt mixtures being intermediate. The influence of sodic salts predominated in the four-salt mixture, and saline salts in the mixture alleviated the inhibitory effect of $\mathrm{Na}_{2} \mathrm{CO}_{3}$ and aggravated the relative weak effect of $\mathrm{NaHCO}_{3}$. For both study species, the salt solution parameters $\mathrm{EC}$, salt content $(\%)$ and $\mathrm{Na}^{+}$ concentration were best correlated with seed/seedling metrics in saline salts and $\mathrm{Na}^{+}$concentration in sodic salts. Water potential and $\mathrm{pH}$ were not good predictors for salt effects at the seedling establishment stage. Future studies on germination and seedling growth of species in salt-affected soils should examine the effects of various saline and sodic salts and the correlation between germination/seedling responses and salt content $(\%)$ and $\mathrm{Na}^{+}$concentration.

Acknowledgements We thank Ms. Zongying Hu for help with the experiments and Prof. Jerry Baskin for his useful comments on the manuscript. This study was funded by the National Basic Research Program of China (2015CB150800) and the National Natural Science Foundation of China (41571055).

\section{References}

Assaha DVM, Ueda A, Saneoka H, Al-Yahyai R, Yaish MW (2017) The role of $\mathrm{Na}^{+}$and $\mathrm{K}^{+}$transporters in salt stress adaptation in glycophytes. Front Physiol 8:509

Bao R, Yin P, Dai J, Guo B, Wei Y (2012) Effects of different media on the transplantation of Huperzia serrate (Thunb.) Trev. Afr J Agric Res 7:3045-3048

Barrett-Lennard EG (2002) Restoration of saline land through revegetation. Agric Water Manag 53:213-226

Basto S, Dorca-Fornell C, Thompson K, Rees M (2013) Effect of $\mathrm{pH}$ buffer solutions on seed germination of Hypericum pulchrum, Campanula rotundifolia and Scabiosa columbaria. Seed Sci Technol 41:298-302

Bina F, Bostani A (2017) Effect of salinity $(\mathrm{NaCl})$ stress on germination and early seedling growth of three medicinal plant species. Adv Life Sci 4:77-83

Dodd GL, Donovan LA (1999) Water potential and ionic effects on germination and seedling growth of two cold desert shrubs. Am J Bot 86:1146-1153

Egan TP, Ungar IA, Meekins JF (1997) The effect of different salts of sodium and potassium on the germination of Atriplex prostrate (Chenopodiaceae). J Plant Nutr 20:1723-1730

Everitt JH (1983) Seed germination characteristics of two woody legumes (Retama and twisted Acacia) from South Texas. J Range Manag 36:411-414

Farissi M, Bouizgaren A, Faghire M, Bargaz A, Ghoulam C (2011) Agro-physiological responses of Moroccan alfalfa (Medicago sativa L.) populations to salt stress during germination and early seedling stages. Seed Sci Technol 39:389-401

Farooq M, Gogoi N, Hussain M, Barthakur S, Paul S, Bharadwaj N, Migdadi HM, Alghamdi SS, Siddique KHM (2017) Effects, tolerance mechanisms and management of salt stress in grain legumes. Plant Physiol Biochem 118:199-217

Flowers TJ, Colmer TD (2008) Salinity tolerance in halophytes. New Phytol 179:945-963 
Flowers TJ, Flowers SA (2005) Why does salinity pose such a difficult problem for plant breeders? Agric Water Manag 78: $15-24$

Flowers TJ, Hajibagheri MA, Clipson NJW (1986) Halophytes. Q Rev Biol 61:313-337

Glenn EP, Anday T, Chaturvedi R, Martinez-Garcia R, Pearlstein S, Soliz D, Nelson SG, Felger RS (2013) Three halophytes for saline-water agriculture: an oilseed, a forage and a grain crop. Environ Exp Bot 92:110-121

Guan B, Zhou D, Zhang H, Tian Y, Japhet W, Wang P (2009) Germination responses of Medicago ruthenica seeds to salinity, alkalinity, and temperature. J Arid Environ 73: 135-138

Gul B, Weber DJ (1999) Effect of salinity, light, and temperature on germination in Allenrolfea occidentalis. Can J Bot 77: 240-246

Guo R, Zhou J, Hao WP, Gong DZ, Zhong XL, Gu FX, Liu Q, Xia X, Tian JN, Li HR (2011) Germination, growth, photosynthesis and ionic balance in Setaria viridis seedlings subjected to saline and alkaline stress. Can J Plant Sci 91:1077-1088

Hanif Z, Naeem M, Ali HH, Tanveer A, Javaid MM, Peerzada AM, Chauhan BS (2017) Effect of environmental factors on germination of Salsola foetida: potential species for rehabilitation of degraded rangelands. Rangel Ecol Manag 70:638-643

Hassan MA, Estrelles E, Soriano P, López-Gresa MP, Bellés JM, Boscaiu M, Vicente O (2017) Unraveling salt tolerance mechanisms in halophytes: a comparative study on four Mediterranean Limonium species with different geographic distribution patterns. Front Plant Sci 8:1438

Huang L, Liu X, Wang Z, Liang Z, Wang M, Liu M, Suarez DL (2017) Interactive effects of $\mathrm{pH}, \mathrm{EC}$ and nitrogen on yields and nutrient absorption of rice (Oryza sativa L). Agric Water Manag 194:48-57

Jesus JM, Danko AS, Fiúza A, Borges MT (2015) Phytoremediation of salt-affected soils: a review of process, applicability, and the impact of climate change. Environ Sci Pollut Res 22:6511-6525

Kanawapee N, Sanitchon J, Lontom W, Threerakulpisut P (2012) Evaluation of salt tolerance at the seedling stage in rice genotypes by growth performance, ion accumulation, proline and chlorophyll content. Plant Soil 358:235-249

Li R, Shi F, Fukuda K (2010a) Interactive effects of salt and alkali stresses on seed germination recovery, and seedling growth of a halophyte Spartina alterniflora (Poaceae). S Afr J Bot 76:380-387

Li R, Shi F, Fukuda K, Yang Y (2010b) Effects of salt and alkali stresses on germination, growth, photosynthesis and ion accumulation in alfalfa (Medicago sativa $\mathrm{L}$ ). Soil Sci Plant Nutr 56:725-733

Lin J, Mu C, Wang Y, Li Z, Li X (2014) Physiological adaptive mechanisms of Leymus chinensis during germination and early seedling stages under saline and alkaline conditions. J Anim Plant Sci 24:904-912

Lin J, Shao S, Wang Y, Qi M, Lin L, Wang Y, Yan X (2016a) Germination responses of the halophyte Chloris virgata to temperature and reduced water potential caused by salinity, alkalinity and drought stress. Grass Forage Sci 71:507-514

Lin JX, Yu DF, Shi YJ, Sheng HC, Li C, Wang YN, Mu CS, Li XY (2016b) Salt-alkali tolerance during germination and establishment of Leymus chinensis in the Songnen grassland of China. Ecol Eng 95:763-769

Lu JM, Zhu JY, Li JD, Zhou DW, Liu JX, Zhao LH (1998) The structure study of four species roots of saline soil in the Songnen plain. Acta Ecol Sin 18:335-337

Ma H, Yang H, Lü X, Pan Y, Wu H, Liang Z, Ooi MKJ (2015) Does high $\mathrm{pH}$ give a reliable assessment of the effect of alkaline soil on seed germination? A case study with Leymus chinensis (Poaceae). Plant Soil 394:35-43

Maas EV, Hoffman GJ (1977) Crop salt tolerance-current assessment. J Irrig Drain Div 103:115-134

Nedjimi B (2017) How $\mathrm{NaCl}, \mathrm{Na}_{2} \mathrm{SO}_{4}, \mathrm{MgCl}_{2}$ and $\mathrm{CaCl}_{2}$ salts affect the germinability of Pinus halepensis mill. Curr Sci 113:2031-2035

Nichols PGH, Malik AI, Stockdale Colmer TD (2009) Salt tolerance and avoidance mechanisms at germination of annual pasture legumes: importance for adaptation to saline environments. Plant Soil 315:241-255

Panta S, Flowers T, Lane P, Doyle R, Haros G, Shabala S (2014) Halophyte agriculture: success stories. Environ Exp Bot 107:71-83

Piovan MJ, Zapperi GM, Pratolongo PD (2014) Seed germination of Atriplex undulata under saline and alkaline conditions. Seed Sci Technol 42:286-292

Qadir M, Ghafoor A, Murtaza G (2000) Amelioration strategies for saline soils: a review. Land Degrad Dev 11:501-521

Qadir M, Quillérou E, Nangia V, Murtaza G, Singh M, Thomas RJ, Drechsel P, Noble AD (2014) Economics of salt-induced land degradation and restoration. Nat Res Forum 38:282-295

Qudir M, Tubeileh A, Akhtar J, Larbi A, Minhas PS, Khan MA (2008) Productivity enhancement of salt-affected environments through crop diversification. Land Degrad Dev 19: 429-453

Ryan J, Miyamoto S, Stroehlein JL (1975) Salt and specific ion effects on germination of four grass. J Range Manag 28:61-64

Shaygan M, Baumgartl T, Amold S (2017) Germination of Atriplex halimus seeds under salinity and water stress. Ecol Eng 102:636-640

Shi D, Wang D (2005) Effects of various salt-alkaline mixed stresses on Aneurolepidium chinense (Trin.) Kitag. Plant Soil 271:15-26

Song J, Feng G, Tian C, Zhang F (2005) Strategies for adaptation of Suaeda physophora, Haloxylon ammodendron and Haloxylon persicum to a saline environment during seedgermination stage. Ann Bot 96:399-405

Soriano P, Moruno F, Boscaiu M, Vicente O, Hurtado A, Llinares JV, Estrelles E (2014) Is salinity the main ecologic factor that shapes the distribution of two endemic Mediterranean plant species of the genus Gypsophila? Plant Soil 384:363-379

Sosa L, Llanes A, Reinoso H, Reginato M, Luna V (2005) Osmotic and specific ion effects on the germination of Prosopis strombulifera. Ann Bot 96:261-267

Sun J, Yang G, Zhang W, Zhang Y (2016) Effects of heterogeneous salinity on growth, water uptake, and tissue ion concentrations of alfalfa. Plant Soil 408:211-226

Ungar IA (1996) Effect of salinity on seed germination, growth, and ion accumulation of Atriplex patula (Chenopodiaceae). Am J Bot 83(5):604-607

Vicente MJ, Conesa E, Álvarez-Rogel J, Franco JA, MartínezSánchez JJ (2009) Relationships between salt type and seed 
germination in three plant species growing in salt marsh soils of semi-arid Mediterranean environments. Arid Land Res Manag 23:103-114

Wehr JB, Kopittke PM, Dalzell SA, Menzies NW (2016) Germination of Leucaena and Rhodes grass seeds in saline and alkaline conditions. Seed Sci Technol 44:1-14

Yang C, Chong J, Li C, Kim C, Shi D, Wang D (2007) Osmotic adjustment and ion balance traits of an alkali resistant halophyte Kochia sieversiana during adaptation to salt and alkali conditions. Plant Soil 294:263-276

Zhang JT, Mu CS (2009) Effects of saline and alkaline stresses on the germination, growth, photosynthesis, ionic balance and anti-oxidant system in an alkali-tolerant leguminous forage Lathyrus quinquenervius. Soil Sci Plant Nutr 55:685-697

Zhang YP, Nan ZB (2007) Growth and anti-oxidative systems changes in Elymus dahuricus is affected by Neotyphodium endophyte under contrasting water availability. J Agron Crop Sci 193:377-386

Zhang Q, Rue K (2014) Alkalinity showed limited effect on turfgrass germination under low moderate salinity. Hortic Sci 49:1201-1204
Zhang H, Zhao Y (2011) Effects of different neutral and alkaline salinities on seed germination and early seedling growth of maize (Zea mays L.) Afr J Agric Res 6: $3515-3521$

Zhang H, Irving LJ, McGill C, Matthew C, Zhou D, Kemp P (2010) The effects of salinity and osmotic stress on barley germination rate: sodium as an osmotic regulator. Ann Bot 106:1027-1035

Zhang HX, Zhou DW, Tian Y, Huang YX, Sun ZW (2013) Comparison of seed germination and early seedling growth responses to salinity and temperature of the halophyte Chloris virgata and the glycophyte Digitaria sanguinalis. Grass Forage Sci 68:596-604

Zhang H, Zhang G, Lü X, Zhou D, Han X (2015) Salt tolerance during seed germination and early seedling stages of 12 halophytes. Plant Soil 388:229-241

Zhao K, Fan H, Ungar IA (2002) Survey of halophyte species in China. Plant Sci 163:491-498

Zhao Y, Lu Z, He L (2014) Effects of saline-alkaline stress on seed germination and seedling growth of Sorghum bicolor (L.) Moench. Appl Biochem Biotechnol 173:1680-1691 